\title{
SOX9 wt Allele
}

National Cancer Institute

\section{Source}

National Cancer Institute. SOX9 wt Allele. NCI Thesaurus. Code C75517.

Human SOX9 wild-type allele is located within 17q24.3-q25.1 and is approximately $5 \mathrm{~kb}$ in length. This allele, which encodes transcription factor SOX-9, plays roles in transcriptional regulation, osteogenesis, chondrogenesis and control of testis development. Mutations in this gene are associated with campomelic dysplasia. 